This document was prepared in conjunction with work accomplished under Contract No. DE-AC09-96SR18500 with the U. S. Department of Energy.

\title{
DISCLAIMER
}

This report was prepared as an account of work sponsored by an agency of the United States Government. Neither the United States Government nor any agency thereof, nor any of their employees, makes any warranty, express or implied, or assumes any legal liability or responsibility for the accuracy, completeness, or usefulness of any information, apparatus, product or process disclosed, or represents that its use would not infringe privately owned rights. Reference herein to any specific commercial product, process or service by trade name, trademark, manufacturer, or otherwise does not necessarily constitute or imply its endorsement, recommendation, or favoring by the United States Government or any agency thereof. The views and opinions of authors expressed herein do not necessarily state or reflect those of the United States Government or any agency thereof.

This report has been reproduced directly from the best available copy.

Available for sale to the public, in paper, from: U.S. Department of Commerce, National Technical Information Service, 5285 Port Royal Road, Springfield, VA 22161, phone: (800) 553-6847, fax: (703) 605-6900

email: orders@ntis.fedworld.gov

online ordering: http://www.ntis.gov/help/index.asp

Available electronically at http://www.osti.gov/bridge

Available for a processing fee to U.S. Department of Energy and its contractors, in paper, from: U.S. Department of Energy, Office of Scientific and Technical Information, P.O. Box 62, Oak Ridge, TN 37831-0062,

phone: (865)576-8401,

fax: (865)576-5728

email: $\underline{\text { reports@ adonis.osti.gov }}$ 


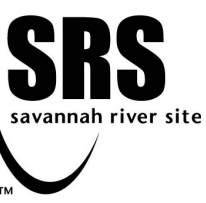

WSRC-TR-2002-00052, Rev. 1

Key Words: Characterization, Tank 19, Tank Closure

\section{Characterization of Tank 19 Residual Waste}

P. D. d'Entremont, 703-H

J. L. Thomas, 742-4G

Publication Date: November 22, 2002 
WSRC-TR-2002-00052

November 22, 2002
Revision 1

Page 2 of 30

Authors

Gaul P.distrem,

P. D. d'Entremont, HLW Process Engineering

$11 / 25 / 02$

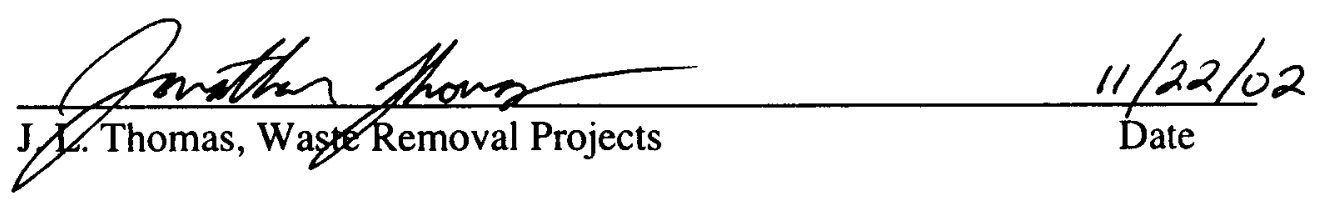

Technical Review

$\frac{\text { W. S. Vemfeet a R.F Servile }}{\text { R. F. Swingle, SRTE Waste Processing Technology }}$

Independent Review

$\begin{array}{ll}\text { Darrel } 6 . \text { Weller } & 1 / 125 / 02 \\ \text { D. D. Walker, SRTC Liquid Waste Processing } & \text { Date }\end{array}$

Approvals

Noel Chapman for per telecon then than g $15 / 22 / 02$
D. B. Little, QST Engineering Manager 
WSRC-TR-2002-00052

Revision 1

November 22, 2002

Page 3 of 30

\section{TABLE OF CONTENTS}

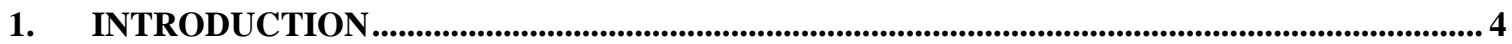

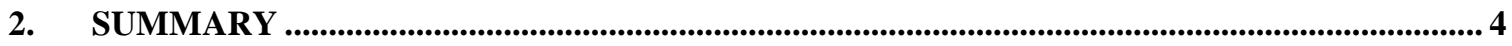

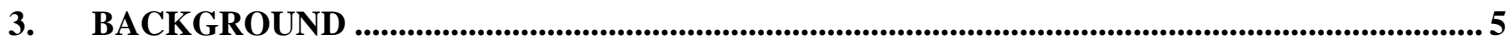

4. WASTE REMOVAL IN PREPARATION FOR TANK CLOSURE ..........................................5

5. ESTIMATING THE TANK 19 RESIDUAL INVENTORIES...................................................5

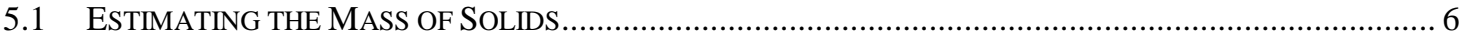

5.1.1 Most of the Solids Were Moved and/or Mixed by Waste Removal....................................... 6

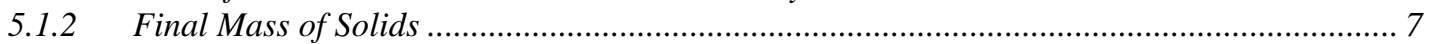

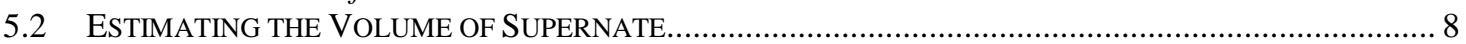

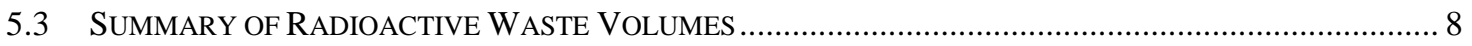

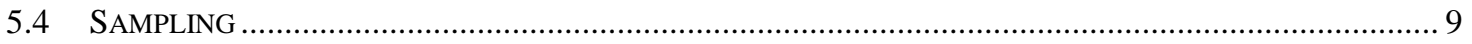

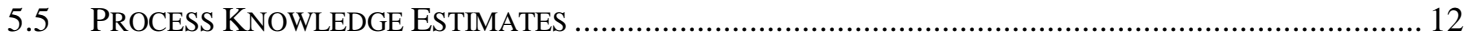

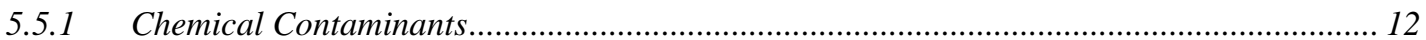

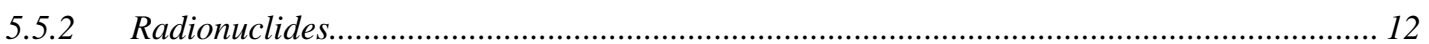

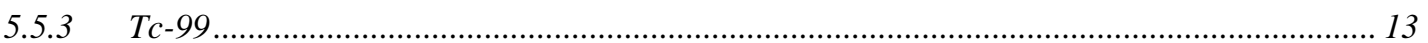

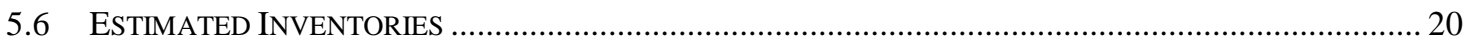

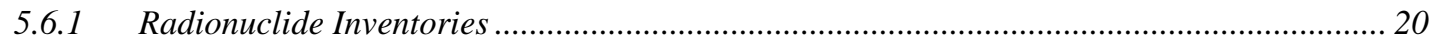

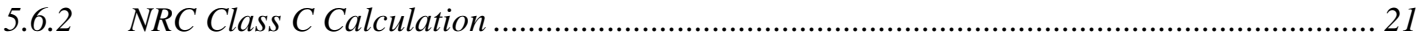

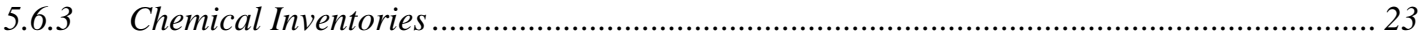

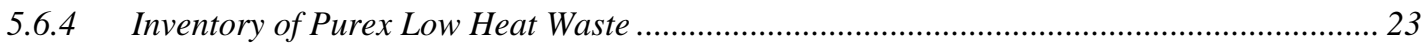

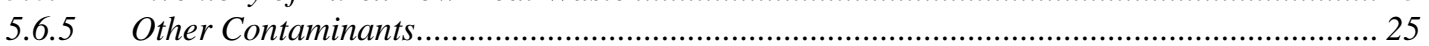

6. ANALYSIS OF POSSIBLE FIXED CONTAMINATION ON THE TANK 19 INTERIOR

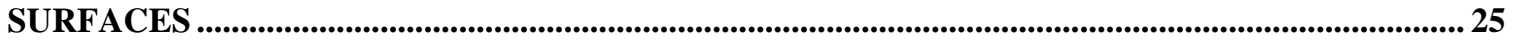

7. REVISION TO F TANK FARM INVENTORY ESTIMATES ..................................................... 25

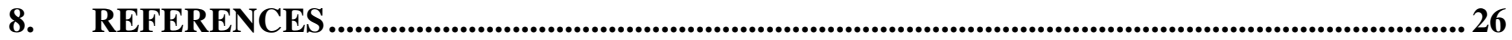

APPENDIX 


\section{Introduction}

Plans are to close Tank 19, a Type IV waste tank in the F-Area Tank Farm, by filling it with pumpable backfill materials. Most of the waste was removed from the tank in the 1980s, and more waste has been removed recently.

To obtain approval for closure, fate and transport groundwater modeling must be performed to ensure that closing the tank with the residual inventory complies with environmental performance standards. This report documents the basis for the residual waste inventories that will be used in the Tank 19 fate and transport modeling.

\section{Summary}

The total residual solids volume in Tank 19 was determined to be 15,000 gallons based on inspections of the tank heel as the liquid level descended during the final supernate pumpdown. The mass of solids on a dry basis is approximately $120,000 \mathrm{lb}$.

Most of the radionuclides in Tank 19 came from Purex Low Heat Waste from F Canyon. Based on the iron content of the residual solids in Tank 19, only about 8 wt \% of the contaminants in Tank 19 came from Purex Low Heat Waste. The remaining solids were derived from the zeolite (initially containing retained Cs-137) from the cesium removal column and the coating waste (which had very low radioactivity) from F Canyon.

The composition of the solids in Tank 19 has been estimated by two methods: 1) samples, and 2) predictions based on the knowledge of the composition of Purex Low Heat Waste. The samples were analyzed for all constituents that are significant from a tank closure standpoint. The inventories reported for these key constituents are based on sample data. For all other radionuclides, the inventories are based on process knowledge estimates.

Samples and observations indicate that, with the exception of one sample of crusty material, the vigorous agitation during waste removal homogenized the solids in the tank, so sampling can be relied upon to give an accurate estimate of the entire tank contents. Visual examinations of the solid surface during pumping operations indicate that at least 92 vol \% of the solids in the tank were moved during waste removal operations. A fulldepth core sample taken from the spot in the tank that had the most potentially unmoved solids had concentrations similar to the other samples, which is further evidence that the tank was homogenized.

For some components, the concentrations measured in samples differed greatly from the concentrations predicted by process knowledge, probably because of the presence of zeolite and degraded forms of zeolite, which are known to be good absorbers of certain cations. The most notable constituent is Cs-137, which is enriched more than three orders of magnitude above its process knowledge estimate. This is expected, because the zeolite that was added to the tank was added specifically because of its high affinity for cesium. Cs-137 has a short enough half-life (30 years) and moves slowly enough through 
the environment so that it does not migrate very far from the tank before decaying away. Thus, this elevated inventory of Cs-137 is not a performance assessment concern. There was also enrichment of Tc-99, although the Tc-99 concentration is still low because the tank contains predominantly solids derived from zeolite and coating waste.

\section{Background}

Tank 19 is a Type IV underground waste storage tank located in the F-Tank Farm. It is a cylindrical-shaped, carbon steel tank with a diameter of 85 feet, a height of 34.25 feet, and a working capacity of 1.3 million gallons. Steel angle stiffener rings around the interior and an outer concrete shell provide support to the liner. The concrete tank dome contains six perimeter risers and one center riser.

Tank 19 was placed in service in 1961 and initially received a small amount of low heat waste from Tank 17. It then served as an evaporator concentrate (saltcake) receiver from February 1962 to September 1976. Tank 19 also received the spent zeolite ion exchange media from a cesium removal column that once operated in the northeast riser of the tank to remove cesium from the evaporator overheads. From July 1980 to August 1981, the Tank 19 salt removal program used two shafted agitation pumps and a telescoping transfer jet assembly to reduce the solids volume in Tank 19 from over one million gallons to an estimated 33,000 gallons.

\section{Waste Removal in Preparation for Tank Closure}

From September 2000 to June 2001, heel removal was performed on the estimated 33,000 gallons of material remaining in Tank 19. In this campaign, three submersible ducted turbine mixers installed in the east, west, and southwest risers operated in varying orientations to suspend solids from the heel into the supernate. A centrifugal transfer pump in the northeast riser was used to transfer the supernate slurry from Tank 19 to Tank 18. Decanted supernate from Tank 18 was recycled back to Tank 19 as the slurry media for each transfer. The southwest mixer, however, failed after 266 hours of operation, and the remaining transfers were performed using only the east and west mixers. These mixers, together with the transfer pump, completed approximately 3,000 hours of mixing and 46 transfers out of Tank 19. In August 2001, a spraywashing waterjet tool in the center riser was used to spray the interior tank walls with inhibited wash water to the highest historical waste level, which was 377 inches from the tank bottom, to dislodge contamination remaining after bulk waste removal.

\section{Estimating the Tank 19 Residual Inventories}

There are two kinds of residual material in Tank 19-solids and supernate (aqueous salt solution). The supernate includes free supernate and interstitial supernate that is trapped in the solids. Tank farm experience shows that the sludges typically contain high amounts of interstitial liquid (70-85 vol \%), and most of the supernate in Tank 19 is in the solids. 
Unlike Tanks 17 and 20, the two tanks that have been previously closed, the inventory of radionuclides in the supernate in Tank 19 must be accounted for to accurately estimate the inventory in the tank. In estimating the inventory in Tank 17 and 20 in preparation for closure, the inventory of radionuclides in the supernate was assumed to be negligible and was not included in the total. ${ }^{1,2}$ The bulk waste removal and spray washing in these tanks was done primarily by adding fresh water with each mixing batch, which washed soluble radionuclides out of the supernate. However, the recent heel removal in Tank 19 was conducted by using primarily recycled supernate from Tank 18 . Since soluble radionuclides were not effectively washed out of the system, the concentrations of radionuclides in the Tank 19 supernate are much higher than in Tanks 17 and 20.

Most of the solids in Tank 19 are on the floor of the tank. However, Tank 19 also has a small inventory of visible solids on the stiffener bands on the inside of the tank.

\subsection{Estimating the Mass of Solids}

The mass of solids in Tank 19 was estimated by first estimating the volume of the wet solids and then applying an estimate of the mass of dry solids per volume of wet solids.

During each waste removal step, the contents of the tank were agitated using submersible turbine mixers and then the supernate was pumped out, removing some of the solids that had been suspended during that step. The volume of wet solids was estimated by observing the liquid/solid interface in the tank while the supernate was being pumped

out. ${ }^{3}$ As the supernate level decreased, the solids began to be observed above the surface of the liquid. At various supernate levels, the "shoreline" where the supernate surface met the solid surface was mapped. By combining the shoreline mappings at various supernate depths, a contour plot, like a topographic map, was developed that showed the solids height at each location in the tank. A separate mapping was developed for each pumping operation that was observed. However, not every pumping operation was mapped.

\subsubsection{Most of the Solids Were Moved and/or Mixed by Waste Removal}

Examination of the contour plots from all of the pumping operations indicate that at least $92 \mathrm{vol} \%$ of the solids in the tank were moved during waste removal, which indicates that the turbine mixers were effective at moving and mixing the contents of the tank. This is one piece of evidence that the solids are relatively homogeneous. The second piece of evidence that the solids are homogeneous is the samples (see section 5.4).

The estimate of $92 \%$ was derived by examining all the contour plots from the various pumping operations and comparing contours at similar levels. For example, if there was a spot in the tank that showed solids at the 3.4-inch level after every pumping operation, then that spot was identified as having more than 3.4 inches of unmoved solids. It was conservatively assumed that the height of solids was at least the next level at which data was available, in this case 5.4 inches. If in any of the pumping operations, only liquid 
WSRC-TR-2002-00052

Revision 1

November 22, 2002

Page 7 of 30

was observed at that spot at the 3.4-inch level, then obviously the solids had been moved by the mixers at that spot.

Note that if a spot showed solids at, for example, 3.4 inches with each pumping operation, that does not necessarily mean that the solids were unmoved. It's possible that the solids were moved but that the mixer operation tended to always deposit solids at this point in the tank. Thus, this analysis technique produced an estimate of the maximum amount of solids that could have been unmoved.

By examining all the spots at each liquid level, a contour plot of possible areas of unmoved solids was developed. ${ }^{3}$ Integrating the area under the contour plot, it was estimated that a maximum of 1,175 gallons of heel might not have moved. This was rounded to 1,200 gallons for this report. Thus, the amount of solids that were not moved by the Flygt mixers is less than $8 \%$ (1,200 gallons divided by 15,000 gallons); at least $92 \%$ of the solids were moved.

\subsubsection{Final Mass of Solids}

The final volume of solids in the tank was estimated from the contour plot developed during the final pumping operation, which occurred on August 23, 2001. For spots in the tank where the solids surface is underneath the liquid surface, it was assumed that the sludge depth was $75 \%$ of the liquid level, which is conservative. Integrating under the contour plot developed during this pumping operation indicates that the tank contains 14,990 gallons of solids, ${ }^{3}$ which was rounded to 15,000 gallons for this report.

The initial issue of this report, published on March 15, 2002, used a sludge bulk density of 1.95 pounds of dry solid per gallon of wet sludge. This was based on previous studies, which demonstrated that, on the average, there are approximately 1.95 pounds of dry sludge solids per gallon of wet settled sludge. ${ }^{4}$ However, in August 2002 a ceramics expert reviewed this report and noted that since the Tank 19 solids were primarily zeolite, the bulk density was likely to be higher than that of settled sludge. As a result of this observation, High-Level Waste Engineering requested the Savannah River Technology Center (SRTC) to measure the bulk density of archived samples of Tank 19 solids, which had not been previously done. SRTC personnel designed experiments to measure this density and carried out the experiments in the SRTC Shielded Cells Facility.

The results of these experiments showed the average bulk density of the Tank 19 samples to be 0.964 gram of dry solid per milliliter of wet sludge ( 8.045 pounds per gallon). ${ }^{5}$ This is indeed higher than the average sludge bulk density of 1.95 pounds per gallon previously used. The estimated mass of dry solids on the floor of Tank 19 is as follows:

$8.045 \frac{\mathrm{lb}}{\mathrm{gal}} \bullet 15,000 \mathrm{gal}=120,000 \mathrm{lb}$

In Tank 19, there were also solids on the stiffener bands around the inside circumference of the tank. Tank 19 has three bands of steel angles that were designed to "stiffen" and 
provide support to the steel tank liner. The top angle protrudes 4 inches from the tank wall, while the bottom two angles extend 5 inches. Historical photographs of Tank 19 show piles of solids built up on these angle bands. Attempts to remove all of these solids during spray washing were unsuccessful, and some solids (on the order of 100 gallons) remain on the angles. To estimate this volume, the cross-sectional shape of the material on the angles was conservatively assumed to be a rectangle formed on one side by the total length of the angle extending out from the tank wall and on the other side by the estimated height of residual material against the tank wall. Video footage of the angle stiffeners was used to estimate the length and height dimensions (along the tank wall axis) of the solids piles.

The estimate of around 100 gallons of solids on the angle stiffeners represents less than $1 \%$ of the total volume of solids in the tank. In light of the other conservatisms taken in estimating the volume and concentrations of the solids and supernate, this solids volume was neglected in calculating the inventories of constituents in the tank.

\subsection{Estimating the Volume of Supernate}

The volume of supernate was estimated using the same contour information that was used to estimate the volume of solids. First of all, sludge contains $70-85 \%$ supernate by volume, i.e., it has the consistency of pudding. As noted previously, Tank 19 is primarily zeolite with more solids per gallon than ordinary sludge, so it is likely to have less entrained supernate than sludge. However, for the purposes of this calculation it was assumed that the sludge contained 85 vol.\% supernate ${ }^{3}$. Thus the volume of supernate in the sludge is estimated as:

\section{$15,000 \mathrm{gal} \bullet 0.85=12,750 \mathrm{gal}$}

In addition to the supernate in the sludge, there is also free supernate above the sludge in the areas of the tank where no sludge is protruding above the liquid surface. As mentioned previously, in these areas it was conservatively assumed that the sludge occupied $75 \%$ of the volume. Assuming the remaining $25 \%$ is free supernate, the estimated free supernate in the tank is 1,800 gallons. Thus, the total estimated volume of supernate in the tank is 12,750 gallons of interstitial supernate plus 1,800 gallons of free supernate, or 14,550 gallons. For the purpose of calculating the supernate radionuclide inventory, this number was rounded up to 15,000 gallons of total supernate.

\subsection{Summary of Radioactive Waste Volumes}

There are 15,000 gallons of wet sludge in the bottom of Tank 19. Based on the assumption in Section 5.2 that $85 \%$ of the heel is interstitial supernate, the 15,000 gallon heel is comprised of 12,750 gallons of interstitial supernate and 2,250 gallons of dry solids. Based on the measured density of the heel material discussed in Section 5.1.2, this assumption underestimates the volume of solids and overestimates the volume of interstitial liquid in the heel. This is conservative in estimating the tank radionuclide and chemical inventories because it increases the estimated inventories in the supernate. 
WSRC-TR-2002-00052

Revision 1

November 22, 2002

Page 9 of 30

Because the solids inventories are calculated on a weight basis, the underestimation of the dry solids volume has no effect on the estimation of the solids inventories. Additionally, there are an estimated 1,800 gallons of free supernate remaining in the tank. The following table summarizes the calculated waste volumes in the bottom of Tank 19 .

\begin{tabular}{lc} 
Dry heel solids & 2,250 gallons \\
Interstitial heel supernate & 12,750 gallons \\
Free supernate & 1,800 gallons \\
\cline { 2 - 2 } Total & 16,800 gallons
\end{tabular}

Therefore, there are 14,550 total gallons of supernate in Tank 19; this number was rounded up to 15,000 gallons to calculate the supernate radionuclide inventory from the supernate sample concentrations. The solids chemical and radionuclide inventories were determined using 120,000 lb of dry solids (calculated in Section 5.1.2).

\subsection{Sampling}

A total of four solids samples and one supernate sample were obtained of the residual materials in Tank 19 immediately preceding and following the waste removal campaign in 2000 and 2001. The results of these samples are documented in Tables 2, 3, and 4. Figure 1 shows the riser locations used to take each of the four samples from the Tank 19 heel.

\section{Figure 1}

\section{Tank 19 Sample Locations}

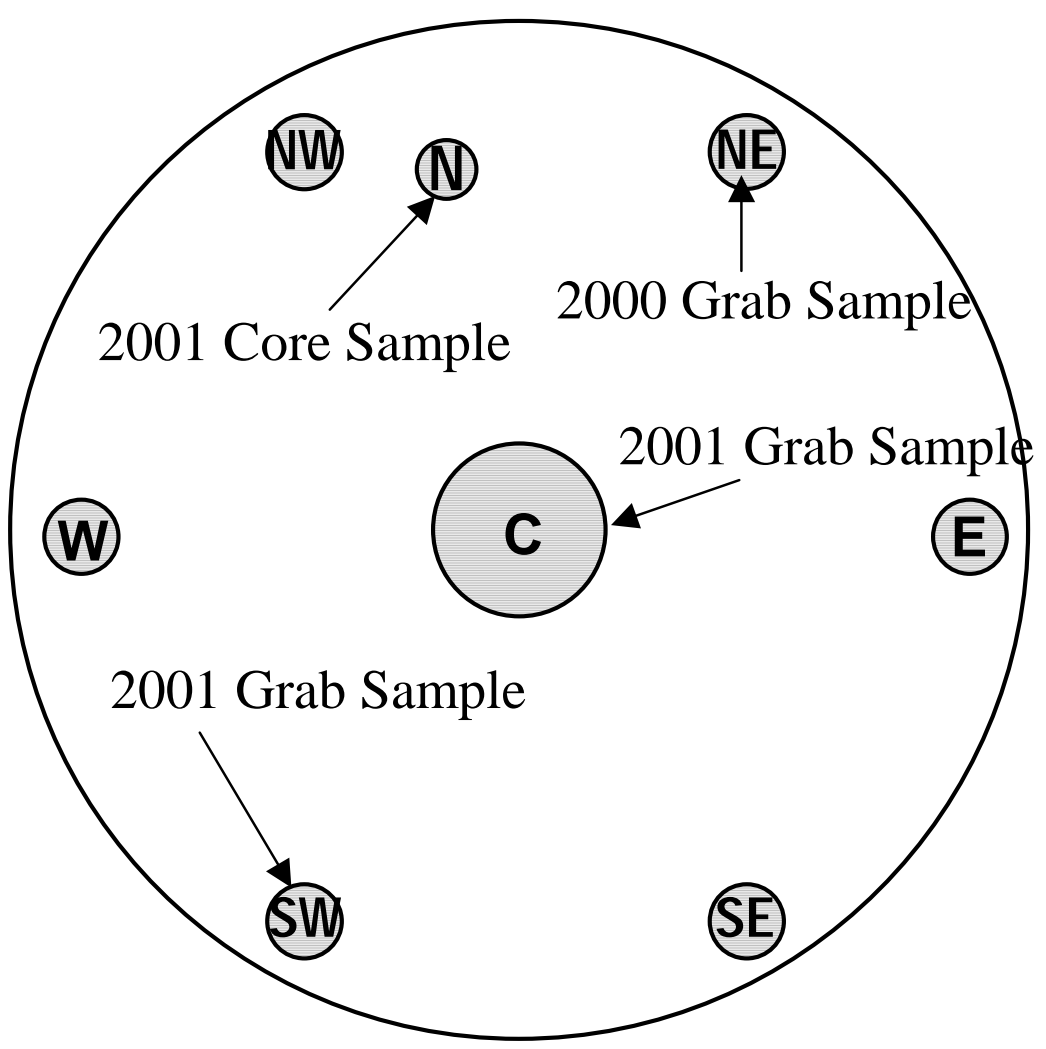


In revision 0 of this report an earlier sample taken in 1996 was also included as one of the samples. However, this sample was taken before the latest waste removal campaign, and the composition may have changed since the sample was taken because waste removal preferentially removed smaller particles, which might have had different composition than the large particles. Also, as part of the review of plutonium and americium analyses for revision 1, it was noted that the plutonium concentrations reported for this sample were markedly higher than the other four. A review of these results indicated that it was likely that the 1996 sample results were off by quite a bit due to the inability of SRTC (in 1996) to perform chemical separations before counting the sample, which improves accuracy considerably. Consequently, the 1996 sample was excluded from the averages used in estimating the tank radionuclide and chemical inventories.

The supernate sample was actually taken from Tank 18. However, as mentioned previously, waste removal from Tank 19 was conducted by slurrying material from Tank 19 to Tank 18, then transferring the liquid from Tank 18 back to Tank 19. Over 40 transfers between the two tanks were made during this waste removal campaign. Thus, the supernate in both tanks is well mixed and is the same composition. At the time of the final sampling, there was very little liquid in Tank 19. Minimizing the amount of liquid in Tank 19 before closure was desirable, because it reduced the residual inventory, but it made it difficult to obtain a liquid sample because there was no liquid under available sample risers. Thus, the sample was taken from Tank 18, which (at the time) held the bulk of the supernate that had been transferred back and forth. The results of the supernate sample are reported in Table 2 and Table 4.

With the exception of one sample, the four solids samples appeared to be the same material and had similar compositions. The one exception was a sample of crusty material that was taken on $12 / 7 / 2000$, before the mixing campaign. This hard, crusty material was on the top of a mound in the position for the transfer pump. The crusty material interfered with the installation of the transfer pump and was sampled to determine its composition. The analysis indicates that this is a different phase that is not typical of the bulk composition of the tank.

The crusty material had lower levels of key radionuclides than the other three samples. The composition of the material is noted in Table 2 and Table 4, but was excluded from the averages used in estimating the tank radionuclide and chemical inventories.

Observation of the tank indicates that the crusty material represented a small volume, and excluding it is conservative because it had lower concentrations of key radionuclides. Also, this material was dissolved with a high pressure hydrolance and subsequently distributed throughout the tank during mixer operation.

One concern in characterizing the solids in Tank 19 was that there may be areas of the tank that were not mixed and that would have a different composition than the bulk solids. As mentioned previously, as much as 1,200 gallons of solids might not have moved during waste removal. 
WSRC-TR-2002-00052

Revision 1

November 22, 2002

Page 11 of 30

To determine the composition of these potentially unmoved solids, a new riser was core drilled through the roof of the tank a few feet east of the northwest riser. The location of the new riser was directly above the area that contained the largest volume of potentially unmoved solids.

A core sample was obtained from this location. The sample was transported to the SRTC High Level Caves, opened, and inspected. A group consisting of employees of SRTC Waste Process Technology (WPT) section and High Level Waste Engineering viewed the core and agreed that it appeared homogeneous. The sample contained coarse solids similar to what had been observed in the previous grab samples. Small portions of the core were archived in case analyses at different depths were desired at a future date. The rest of the core was mixed and analyzed.

The core sample results are quite similar to the other grab samples, confirming that the composition of the potentially unmoved core is about the same as the bulk solids that have been mixed. Perhaps this potentially unmoved mound had actually been moved, but the mixing patterns used during waste removal left a mound in this location each time the solids were mapped. Descriptions of the four samples taken of the residual solids in Tank 19 are shown in Table 1.

\section{Table 1}

\section{Samples from Tank 19}

\begin{tabular}{|c|c|c|c|c|c|}
\hline No & $\begin{array}{l}\text { Sample } \\
\text { Date }\end{array}$ & $\begin{array}{l}\text { Description of } \\
\text { Sample }\end{array}$ & Reason for Sample & $\begin{array}{l}\text { Sample } \\
\text { No. }\end{array}$ & $\begin{array}{l}\text { Composition } \\
\text { reported in }\end{array}$ \\
\hline 1 & $12 / 2000$ & $\begin{array}{l}\text { Grab sample of } \\
\text { surface solids } \\
\text { under northeast } \\
\text { riser }\end{array}$ & $\begin{array}{l}\text { Characterize the crusty } \\
\text { material that was } \\
\text { blocking installation of } \\
\text { the transfer pump }\end{array}$ & NA & Reference 6 \\
\hline 2 & 9/2001 & $\begin{array}{l}\text { Grab sample } \\
\text { under center } \\
\text { riser }\end{array}$ & $\begin{array}{l}\text { Characterize bulk solids } \\
\text { in preparation for tank } \\
\text { closure }\end{array}$ & FTF-075 & $\begin{array}{l}\text { References } 7 \\
\text { and } 11\end{array}$ \\
\hline 3 & 9/2001 & $\begin{array}{l}\text { Grab sample } \\
\text { under southwest } \\
\text { riser }\end{array}$ & $\begin{array}{l}\text { Characterize bulk solids } \\
\text { in preparation for tank } \\
\text { closure }\end{array}$ & FTF-077 & $\begin{array}{l}\text { References } 7 \\
\text { and } 11\end{array}$ \\
\hline 4 & $12 / 2001$ & $\begin{array}{l}\text { Core sample } \\
\text { under new riser } \\
\text { cored in tank } \\
\text { roof over } \\
\text { potentially } \\
\text { unmoved mound }\end{array}$ & $\begin{array}{l}\text { Compare the } \\
\text { composition of } \\
\text { potentially unmoved } \\
\text { solids to the bulk solids } \\
\text { that have been moved } \\
\text { by the mixers }\end{array}$ & FTF-118 & $\begin{array}{l}\text { References } 7 \\
\text { and } 11\end{array}$ \\
\hline 5 & 9/2001 & $\begin{array}{l}\text { Dip sample of } \\
\text { liquid from Tank } \\
18\end{array}$ & $\begin{array}{l}\text { Determine the } \\
\text { composition of } \\
\text { supernate in the Tank } \\
18-19 \text { system }\end{array}$ & FTF-076 & Reference 7 \\
\hline
\end{tabular}




\subsection{Process Knowledge Estimates}

Radionuclide estimates of the composition of residual solids in Tank 19 were derived from the Waste Characterization System (WCS). ${ }^{8}$ It is estimated that only about $8 \mathrm{wt} \%$ of the residual material in Tank 19 was derived from Purex Low Heat Waste, which is the waste that is tracked by the WCS (see section 5.6.4, "Inventory of Purex Low Heat Waste").

The inventories and compositions of major sludge constituents in WCS are based on tank fill histories and sludge transfers from the canyons to the tank farms and between tanks. WCS contains the following information about each sludge transfer:

- Date

- Source - canyon vessel or HLW tank

- Destination - HLW tank

- Process - PUREX or H Modified (HM)

- Stream - High Heat Waste (HHW), Low Heat Waste (LHW), or Mixed

- Volume

- Major chemical compound weights - $\mathrm{Fe}(\mathrm{OH})_{3}, \mathrm{NaAlO}_{2}, \mathrm{Ni}(\mathrm{OH})_{2}$, and $\mathrm{MnO}_{2}$

- Major actinide weights - Th-232, U-233, U-234, U-235, U-236, U-238, Np-237, Pu238, $\mathrm{Pu}-239, \mathrm{Pu}-240, \mathrm{Pu}-241$, and $\mathrm{Pu}-242$

\subsubsection{Chemical Contaminants}

No process knowledge estimates were developed for chemical inventories in Tank 19. The inventory estimates for chemical contaminants in Tank 19 were based on samples alone. In the tanks previously closed, Tanks 17 and 20, the chemistry of the waste was well known, and the contents of the tank had been homogenized using slurry pumps. Therefore, process knowledge was used to predict the chemical inventories in these tanks. However, in Tank 19, reactions between the various compounds added to the tank have created new compounds, and video of the interior of the tank indicated it might not be homogeneous.

\subsubsection{Radionuclides}

WCS computes the inventory of fission and activation products (H-3 through Eu-155 in Table 3) using concentrations based on yield distributions in SRS reactor assemblies, solubility data, and other information. The concentrations predicted by WCS were used to estimate the inventory in Tank 19, with the exception of Tc-99, which is discussed in the section below.

WCS computes the inventory of sludge actinides (U-232 through Cm-245 in Table 3) using a combination of techniques used for chemicals and fission and activation products. The mass of major actinides in each transfer are known from canyon accountability 
records or process records. The concentration of minor actinides was estimated from yield distributions in SRS reactor assemblies. WCS also includes decay calculations.

Similar to the treatment for chemical constituents, the concentration of each radionuclide in Tank 19 was computed by dividing the estimated inventory of that radionuclide fed to the tank by the estimated total mass of sludge fed to the tank. Each of these concentrations was then multiplied by the estimated mass of sludge remaining in Tank 19 to derive the WCS inventories that are reported in Table 3.

\subsubsection{Tc-99}

The predicted tank inventory reported for the WCS estimate in Table 3 for Tc-99 is based on an adjusted concentration that is 13.5 times the concentration originally reported by WCS. This is the only nuclide for which the process knowledge concentration has been adjusted. The value for this radionuclide was adjusted for two reasons:

- The performance evaluation predicts that the dose at the seepline will be predominantly due to Tc-99. Therefore, it is important to estimate this radionuclide conservatively.

- Sample results indicated that the concentration of Tc-99 in the residual sludge in Tanks 17 and 20 was elevated relative to the concentration predicted by WCS for the bulk sludge in these tanks. In particular, the ratio of Tc-99 to iron (iron is an indicator for sludge) was extremely high in Tank 20 . The Tc-99 in Tank 17 was also enriched relative to WCS predictions, although not to the same extent as Tank 20.

The adjustment factor of 13.5 was chosen in September 1996 based on sample results from Tank 20. At that time the Tc-99 concentration predicted for Tank 20 by process knowledge was $6.95 \mathrm{E}-05 \mathrm{Ci} / \mathrm{kg}$, whereas the measured concentration in the Tank 20 sludge was $0.94 \mathrm{microCi} / \mathrm{gm}$, which is equivalent to $9.4 \mathrm{E}-04 \mathrm{Ci} / \mathrm{kg} .{ }^{9}$ Since that time, the process knowledge estimate has changed slightly due to refinements in the method of calculation. However, the error introduced by using the old adjustment factor is small relative to other conservative assumptions, so there are no plans to revise the Tank 20 performance evaluation.

The need for the adjustment factor is thought to be due to the fact that Tc-99 behaves differently from other fission products. WCS predicts that most of the fission products go to High-Heat Waste, which is the waste produced by the first cycle of solvent extraction in the Purex process used in the SRS Canyons. However, less Tc-99 is removed in the first cycle than other fission products, so Low Heat Waste (the kind of waste in Tank 19) is enriched in Tc-99. Perhaps after a number of tank closures it may be possible to identify standard factors that can be incorporated into WCS.

In Tank 19, the concentration of Tc-99 is about 60 times the value predicted from process knowledge. The average measured concentration from the solids samples is $0.095 \mu \mathrm{Ci} / \mathrm{gm}$ versus a predicted concentration of $1.597 \mathrm{E}-06 \mathrm{Ci} / \mathrm{kg}$, which is equivalent to $0.001597 \mu \mathrm{Ci} / \mathrm{gm}$. If one assumes that a factor of around 13.5 is due to the fact that 
WSRC-TR-2002-00052

Revision 1

November 22, 2002

Page 14 of 30

more Tc-99 was sent to the tank than predicted by WCS, this still suggests that Tc-99 has been enriched by an additional factor of 4 . The mechanism for this enrichment is unknown. However, it may be due to either sorption of the Tc-99 onto the zeolite and degraded forms of zeolite in the tank or the reduction of pertechnetate to insoluble $\mathrm{TcO}_{2}$. 
WSRC-TR-2002-00052

Revision 1

November 22, 2002

Page 15 of 30

Table 2

\section{Radionuclide Concentrations from Solids and Supernate Samples}

\begin{tabular}{|c|c|c|c|c|c|c|c|}
\hline & & & & & & & Supernate: \\
\hline \multirow[t]{2}{*}{$\begin{array}{c}\text { Radio- } \\
\text { nuclides }\end{array}$} & $\begin{array}{c}\text { No. } 1 \\
\text { Crusty Solids } \\
\text { Dec-00 }\end{array}$ & $\begin{array}{c}\text { No.2 } \\
\text { Bulk Solids } \\
\text { Sept-01 }\end{array}$ & $\begin{array}{c}\text { No. } 3 \\
\text { Bulk Solids } \\
\text { Sept-01 }\end{array}$ & $\begin{array}{c}\text { No. } 4 \\
\text { Cored Solids } \\
\text { Dec-01 }\end{array}$ & $\begin{array}{c}\text { Average } \\
\text { Excluding } \\
\text { Crusty Solids }\end{array}$ & $\begin{array}{c}\text { Std. Dev. } \\
\text { Excluding } \\
\text { Crusty Solids }\end{array}$ & $\begin{array}{l}\text { Dip Sample } \\
\text { from Tank } 18\end{array}$ \\
\hline & (microCi/g) & (microCi/g) & (microCi/g) & (microCi/g) & (microCi/g) & (microCi/g) & (MicroCi/Liter) \\
\hline & & & & & & & \\
\hline \multicolumn{8}{|l|}{ C-14 } \\
\hline \multicolumn{8}{|l|}{$\mathrm{Ni}-59$} \\
\hline \multicolumn{8}{|l|}{ Co-60 } \\
\hline Se-79 & & $<6.46 \mathrm{E}-04$ & $<8.67 \mathrm{E}-04$ & $<4.48 \mathrm{E}-04$ & $6.54 \mathrm{E}-04$ & $2.10 \mathrm{E}-04$ & $<0.0226$ \\
\hline Sr-90 & 0.530 & $<16.8$ & $<16.9$ & 0.658 & 11.45 & 9.35 & \\
\hline \multicolumn{8}{|l|}{ Y-90 } \\
\hline Tc-99 & 0.0205 & 0.0868 & 0.0888 & 0.109 & 0.095 & 0.012 & 7.13 \\
\hline \multicolumn{8}{|l|}{ Ru-106 } \\
\hline \multicolumn{8}{|l|}{ Rh-106 } \\
\hline \multicolumn{8}{|l|}{ Sb-125 } \\
\hline \multicolumn{8}{|l|}{ Sn-126 } \\
\hline \multicolumn{8}{|l|}{$\mathrm{I}-129$} \\
\hline \multicolumn{8}{|l|}{ Cs-134 } \\
\hline \multicolumn{8}{|l|}{ Cs-135 } \\
\hline Cs-137 & 62.8 & 791 & 821 & 862 & 825 & 36 & 4360 \\
\hline \multicolumn{8}{|l|}{ Ce-144 } \\
\hline \multicolumn{8}{|l|}{ Pr-144 } \\
\hline \multicolumn{8}{|l|}{ Pm-147 } \\
\hline \multicolumn{8}{|l|}{ Eu-154 } \\
\hline \multicolumn{8}{|l|}{ Eu-155 } \\
\hline \multicolumn{8}{|l|}{ U-232 } \\
\hline U-233 & $6.28 \mathrm{E}-04$ & $<0.0106$ & $<0.0107$ & $1.28 \mathrm{E}-03$ & $9.72 \mathrm{E}-03$ & $1.62 \mathrm{E}-03$ & $<0.0466$ \\
\hline U-234 & 7.49E-04 & $<6.85 \mathrm{E}-03$ & $<6.90 \mathrm{E}-03$ & $8.07 \mathrm{E}-04$ & $4.85 \mathrm{E}-03$ & $3.50 \mathrm{E}-03$ & $<0.0301$ \\
\hline U-235 & $8.56 \mathrm{E}-06$ & 1.79E-05 & 1.33E-05 & $1.98 \mathrm{E}-05$ & $1.70 \mathrm{E}-05$ & $3.34 \mathrm{E}-06$ & 7.82E-05 \\
\hline U-236 & $1.99 \mathrm{E}-05$ & $<7.09 \mathrm{E}-05$ & $<7.14 \mathrm{E}-05$ & $<3.75 \mathrm{E}-05$ & $5.99 \mathrm{E}-05$ & 1.94E-05 & $<3.11 \mathrm{E}-04$ \\
\hline U-238 & $2.80 \mathrm{E}-04$ & 5.81E-04 & 4.49E-04 & $6.81 \mathrm{E}-04$ & $5.70 \mathrm{E}-04$ & $1.16 \mathrm{E}-04$ & $2.19 \mathrm{E}-03$ \\
\hline $\mathrm{Np}-237$ & $1.98 \mathrm{E}-04$ & $<7.73 \mathrm{E}-04$ & $<7.78 \mathrm{E}-04$ & $<1.61 \mathrm{E}-04$ & $5.71 \mathrm{E}-04$ & 3.55E-04 & $<3.39 E-03$ \\
\hline Pu-238 & 0.505 & $0.377^{\star}$ & $0.253^{*}$ & $0.285^{\star}$ & 0.305 & 0.06 & 0.963 \\
\hline Pu-239 & 0.155 & $0.489^{*}$ & $0.400^{*}$ & $0.315^{*}$ & 0.401 & 0.087 & 0.430 \\
\hline Pu-240 & 0.0575 & $0.169^{*}$ & $0.142^{*}$ & $0.107^{\star}$ & 0.139 & 0.031 & $<1.10$ \\
\hline Pu-241 & & $0.941^{*}$ & $0.810^{*}$ & $0.794^{*}$ & 0.848 & 0.08 & 1.32 \\
\hline Pu-242 & $2.88 \mathrm{E}-04$ & $<4.19 \mathrm{E}-03$ & $<4.21 \mathrm{E}-03$ & $<4.82 E-04$ & $2.96 \mathrm{E}-03$ & $2.15 \mathrm{E}-03$ & $<0.0184$ \\
\hline Am-241 & & $0.179^{*}$ & $0.126^{*}$ & $0.083^{*}$ & 0.129 & 0.048 & $<0.154$ \\
\hline \multicolumn{8}{|l|}{ Am-242m } \\
\hline \multicolumn{8}{|l|}{$\mathrm{Cm}-244$} \\
\hline $\mathrm{Cm}-245$ & & & & & & & \\
\hline & & & & & & & \\
\hline
\end{tabular}

*These concentrations are from WSRC-TR-2002-00540 (Reference 11). All other concentrations are from References 6 and 7. 
WSRC-TR-2002-00052

Revision 1

November 22, 2002

Page 16 of 30

Table 3

\section{Tank 19 Radionuclide Inventories}

\begin{tabular}{|c|c|c|c|c|c|c|c|}
\hline $\begin{array}{l}\text { Radio- } \\
\text { nuclides }\end{array}$ & $\begin{array}{c}\text { Solids } \\
\text { Concentration } \\
\text { Predicted } \\
\text { from WCS } \\
\text { Data as of } \\
1 / 14 / 02\end{array}$ & $\begin{array}{l}\text { Predicted } \\
\text { Solids Tank } \\
\text { Inventory } \\
\text { Based on } \\
\text { WCS Data }\end{array}$ & $\begin{array}{c}\text { Upper 95\% } \\
\text { Confidence Limit } \\
\text { of Solids } \\
\text { Concentration } \\
\text { Based on Solids } \\
\text { Sample Data }\end{array}$ & $\begin{array}{l}\text { Predicted } \\
\text { Solids } \\
\text { Inventory } \\
\text { Based on } \\
\text { Sample Data }\end{array}$ & $\begin{array}{l}\text { Solids Inventory } \\
\text { Best Estimate } \\
\text { (Based on } \\
\text { Sample and } \\
\text { WCS data) }\end{array}$ & $\begin{array}{c}\text { Supernate } \\
\text { Inventory } \\
\text { Estimate } \\
\text { (Based on } \\
15,000 \text { gal) }\end{array}$ & $\begin{array}{c}\text { Total } \\
\text { Inventory } \\
\text { Estimate } \\
\text { (Sludge + } \\
\text { Supernate) }\end{array}$ \\
\hline & (Ci/kg) & (Ci) & (microCi/g) & (Ci) & (Ci) & (Ci) & (Ci) \\
\hline $\mathrm{H}-3$ & $0.000 \mathrm{E}+00$ & $0.00 \mathrm{E}+00$ & & & $0.00 \mathrm{E}+00$ & $3.88 \mathrm{E}-01$ & $3.88 \mathrm{E}-01$ \\
\hline$C-14$ & 1.8919E-08 & $1.04 \mathrm{E}-03$ & & & $1.04 \mathrm{E}-03$ & & $1.04 \mathrm{E}-03$ \\
\hline $\mathrm{Ni}-59$ & $1.113 \mathrm{E}-06$ & $6.09 \mathrm{E}-02$ & & & $6.09 \mathrm{E}-02$ & & $6.09 \mathrm{E}-02$ \\
\hline Co-60 & $9.729 \mathrm{E}-06$ & 5.33E-01 & & & 5.33E-01 & & 5.33E-01 \\
\hline Se-79 & $9.204 \mathrm{E}-08$ & $5.04 \mathrm{E}-03$ & $1.01 \mathrm{E}-03$ & 0.0551 & $5.51 \mathrm{E}-02$ & $1.28 \mathrm{E}-03$ & $5.64 \mathrm{E}-02$ \\
\hline Sr-90 & 4.835E-03 & $2.65 \mathrm{E}+02$ & 27.2 & 1490 & $1.49 \mathrm{E}+03$ & & $1.49 \mathrm{E}+03$ \\
\hline$Y-90$ & 4.835E-03 & $2.65 \mathrm{E}+02$ & & & $2.65 \mathrm{E}+02$ & & $2.65 \mathrm{E}+02$ \\
\hline Tc-99 & 2.156E-05 & $1.18 \mathrm{E}+00$ & 0.116 & 6.33 & $6.33 \mathrm{E}+00$ & 4.05E-01 & $6.73 \mathrm{E}+00$ \\
\hline Ru-106 & 3.635E-10 & 1.99E-05 & & & $1.99 \mathrm{E}-05$ & & $1.99 \mathrm{E}-05$ \\
\hline Rh-106 & 3.635E-10 & 1.99E-05 & & & $1.99 \mathrm{E}-05$ & & 1.99E-05 \\
\hline Sb-125 & 3.487E-06 & $1.91 \mathrm{E}-01$ & & & $1.91 \mathrm{E}-01$ & & 1.91E-01 \\
\hline Sn-126 & $1.710 \mathrm{E}-07$ & $9.36 \mathrm{E}-03$ & & & $9.36 \mathrm{E}-03$ & & $9.36 \mathrm{E}-03$ \\
\hline $\mid-129$ & $7.578 \mathrm{E}-12$ & $4.15 \mathrm{E}-07$ & & & $4.15 \mathrm{E}-07$ & & $4.15 \mathrm{E}-07$ \\
\hline Cs-134 & $1.010 \mathrm{E}-08$ & $5.53 \mathrm{E}-04$ & & & $5.53 \mathrm{E}-04$ & & $5.53 \mathrm{E}-04$ \\
\hline Cs-135 & $1.066 \mathrm{E}-09$ & $5.84 \mathrm{E}-05$ & & & $5.84 \mathrm{E}-05$ & & $5.84 \mathrm{E}-05$ \\
\hline Cs-137 & 3.349E-04 & $1.83 \mathrm{E}+01$ & 885 & 48429 & $4.84 \mathrm{E}+04$ & $2.48 \mathrm{E}+02$ & $4.87 \mathrm{E}+04$ \\
\hline $\mathrm{Ce}-144$ & $4.993 \mathrm{E}-12$ & $2.73 \mathrm{E}-07$ & & & $2.73 \mathrm{E}-07$ & & $2.73 \mathrm{E}-07$ \\
\hline Pr-144 & $4.993 \mathrm{E}-12$ & $2.73 \mathrm{E}-07$ & & & $2.73 \mathrm{E}-07$ & & $2.73 \mathrm{E}-07$ \\
\hline Pm-147 & 5.596E-05 & $3.06 \mathrm{E}+00$ & & & $3.06 \mathrm{E}+00$ & & $3.06 \mathrm{E}+00$ \\
\hline Eu-154 & $1.978 \mathrm{E}-05$ & $1.08 \mathrm{E}+00$ & & & $1.08 \mathrm{E}+00$ & & $1.08 \mathrm{E}+00$ \\
\hline Eu-155 & $0.00 \mathrm{E}+00$ & $0.00 \mathrm{E}+00$ & & & $0.00 \mathrm{E}+00$ & & $0.00 \mathrm{E}+00$ \\
\hline U-232 & $2.819 \mathrm{E}-10$ & $1.54 \mathrm{E}-05$ & & & $1.54 \mathrm{E}-05$ & & $1.54 \mathrm{E}-05$ \\
\hline U-233 & $0.000 \mathrm{E}+00$ & $0.00 \mathrm{E}+00$ & 0.0124 & 0.681 & $6.81 \mathrm{E}-01$ & $2.65 \mathrm{E}-03$ & $6.84 \mathrm{E}-01$ \\
\hline U-234 & $0.000 \mathrm{E}+00$ & $0.00 \mathrm{E}+00$ & 0.0108 & 0.589 & 5.89E-01 & 1.71E-03 & 5.90E-01 \\
\hline U-235 & 1.848E-09 & $1.01 \mathrm{E}-04$ & $2.26 \mathrm{E}-05$ & $1.24 \mathrm{E}-03$ & $1.24 \mathrm{E}-03$ & 4.44E-06 & $1.24 \mathrm{E}-03$ \\
\hline U-236 & $0.000 \mathrm{E}+00$ & $0.00 \mathrm{E}+00$ & $9.27 \mathrm{E}-05$ & 5.07E-03 & 5.07E-03 & 1.77E-05 & 5.09E-03 \\
\hline U-238 & $1.688 \mathrm{E}-07$ & 9.24E-03 & 7.67E-04 & 4.20E-02 & 4.20E-02 & $1.24 \mathrm{E}-04$ & 4.21E-02 \\
\hline $\mathrm{Np}-237$ & $0.000 \mathrm{E}+00$ & $0.00 \mathrm{E}+00$ & 1.17E-03 & 0.0640 & $6.40 \mathrm{E}-02$ & 1.92E-04 & 6.42E-02 \\
\hline Pu-238 & $6.928 \mathrm{E}-04$ & $3.79 \mathrm{E}+01$ & 0.41 & 22.6 & $2.26 \mathrm{E}+01$ & 5.47E-02 & $2.27 E+01$ \\
\hline Pu-239 & 9.897E-05 & $5.42 \mathrm{E}+00$ & 0.548 & 30.00 & $3.00 \mathrm{E}+01$ & 2.44E-02 & $3.00 \mathrm{E}+01$ \\
\hline Pu-240 & 2.212E-05 & $1.21 \mathrm{E}+00$ & 0.192 & 10.50 & $1.05 \mathrm{E}+01$ & $6.25 \mathrm{E}-02$ & $1.06 \mathrm{E}+01$ \\
\hline Pu-241 & 2.964E-03 & $1.62 \mathrm{E}+02$ & 0.98 & 54 & $5.39 \mathrm{E}+01$ & 7.49E-02 & $5.40 \mathrm{E}+01$ \\
\hline Pu-242 & $4.551 \mathrm{E}-08$ & 2.49E-03 & $6.58 \mathrm{E}-03$ & 0.360 & $3.60 \mathrm{E}-01$ & 1.04E-03 & $3.61 \mathrm{E}-01$ \\
\hline Am-241 & $2.75 \mathrm{E}-04$ & $1.50 \mathrm{E}+01$ & 0.210 & 11.51 & $1.15 \mathrm{E}+01$ & 8.74E-03 & $1.15 E+01$ \\
\hline Am-242m & $0.000 \mathrm{E}+00$ & $0.00 \mathrm{E}+00$ & & & $0.00 \mathrm{E}+00$ & & \\
\hline $\mathrm{Cm}-244$ & 4.09E-09 & 2.24E-04 & & & $2.24 \mathrm{E}-04$ & & $2.24 \mathrm{E}-04$ \\
\hline $\mathrm{Cm}-245$ & $2.64 \mathrm{E}-15$ & $1.45 \mathrm{E}-10$ & & & $1.45 \mathrm{E}-10$ & & $1.45 \mathrm{E}-10$ \\
\hline
\end{tabular}


WSRC-TR-2002-00052

Revision 1

November 22, 2002

Page 17 of 30

\section{Table 4}

\section{Chemical Concentrations from Solids and Supernate Samples}

\begin{tabular}{|c|c|c|c|c|c|c|}
\hline \multirow{3}{*}{ Species } & \multicolumn{5}{|c|}{ Solids: } & \multirow{2}{*}{$\begin{array}{c}\text { Supernate: } \\
\text { Dip Sample } \\
\text { from } \\
\text { Tank } 18\end{array}$} \\
\hline & $\begin{array}{c}\text { No. } 1 \\
\text { Crusty Solids } \\
\text { Dec-00 }\end{array}$ & $\begin{array}{c}\text { No.2 } \\
\text { Bulk Solids } \\
\text { Sept-01 }\end{array}$ & $\begin{array}{c}\text { No. } 3 \\
\text { Bulk Solids } \\
\text { Sept-01 }\end{array}$ & $\begin{array}{c}\text { No. } 4 \\
\text { Cored Solids } \\
\text { Dec-01 }\end{array}$ & $\begin{array}{c}\text { Average } \\
\text { Excluding } \\
\text { Crusty Solids }\end{array}$ & \\
\hline & (wt. \%) & (wt. \%) & (wt. \%) & (wt. \%) & (wt. \%) & $(\mathrm{mg} / \mathrm{L})$ \\
\hline Silver & & $6.18 \mathrm{E}-03$ & $5.88 \mathrm{E}-03$ & $2.06 \mathrm{E}-02$ & 1.09E-02 & \\
\hline Aluminum & $1.53 \mathrm{E}+01$ & $1.44 \mathrm{E}+01$ & $1.39 \mathrm{E}+01$ & $1.24 \mathrm{E}+01$ & $1.36 \mathrm{E}+01$ & 3,340 \\
\hline Boron & $2.90 \mathrm{E}-03$ & $1.00 \mathrm{E}-02$ & $\leq 4.40 \mathrm{E}-03$ & $\leq 5.71 \mathrm{E}-03$ & $6.70 \mathrm{E}-03$ & 0.599 \\
\hline Barium & $2.85 \mathrm{E}-02$ & 7.13E-02 & $9.55 \mathrm{E}-02$ & $1.04 \mathrm{E}-01$ & $9.03 \mathrm{E}-02$ & $<0.301$ \\
\hline Calcium & $1.48 \mathrm{E}+00$ & 7.90E-01 & $8.36 \mathrm{E}-01$ & $1.10 \mathrm{E}+00$ & $9.08 \mathrm{E}-01$ & $<0.100$ \\
\hline Cadmium & $5.69 \mathrm{E}-03$ & 1.07E-02 & $9.67 \mathrm{E}-03$ & $8.83 \mathrm{E}-03$ & 9.73E-03 & $\leq 0.251$ \\
\hline Cerium & & $<3.56 \mathrm{E}-01$ & $<3.59 \mathrm{E}-01$ & $<3.32 \mathrm{E}-01$ & 3.49E-01 & \\
\hline Cobalt & $1.00 \mathrm{E}-02$ & $6.05 \mathrm{E}-03$ & $7.40 \mathrm{E}-03$ & $1.12 \mathrm{E}-02$ & 8.22E-03 & $<0.301$ \\
\hline Chromium & $2.57 \mathrm{E}-02$ & 3.86E-02 & $3.22 \mathrm{E}-02$ & $3.54 \mathrm{E}-02$ & 3.54E-02 & 25.9 \\
\hline Copper & $3.39 \mathrm{E}-03$ & $<4.46 \mathrm{E}-03$ & $<4.50 \mathrm{E}-03$ & $4.82 \mathrm{E}-03$ & 4.59E-03 & $<0.301$ \\
\hline Iron & $1.46 \mathrm{E}+00$ & $1.64 \mathrm{E}+00$ & $1.90 \mathrm{E}+00$ & $2.20 \mathrm{E}+00$ & $1.91 \mathrm{E}+00$ & $<0.401$ \\
\hline Lanthanum & $2.70 \mathrm{E}-02$ & $<9.92 E-03$ & $<9.96 \mathrm{E}-03$ & $2.39 \mathrm{E}-02$ & 1.46E-02 & $<1.000$ \\
\hline Lithium & $4.70 \mathrm{E}-03$ & 4.07E-03 & $4.18 \mathrm{E}-03$ & $\leq 2.85 \mathrm{E}-03$ & 3.70E-03 & $<0.301$ \\
\hline Magnesium & $4.08 \mathrm{E}-01$ & $2.40 \mathrm{E}-01$ & $2.55 \mathrm{E}-01$ & $2.59 \mathrm{E}-01$ & $2.51 \mathrm{E}-01$ & $<0.100$ \\
\hline Manganese & $6.06 \mathrm{E}-02$ & $1.42 \mathrm{E}-01$ & $1.45 \mathrm{E}-01$ & $1.23 \mathrm{E}-01$ & 1.36E-01 & $<0.100$ \\
\hline Molybdenum & $7.24 \mathrm{E}-03$ & $\leq 1.01 \mathrm{E}-02$ & $\leq 8.71 \mathrm{E}-03$ & $\leq 8.76 \mathrm{E}-03$ & $9.20 \mathrm{E}-03$ & 2.59 \\
\hline Sodium & & $1.74 \mathrm{E}+01$ & $1.70 \mathrm{E}+01$ & $1.61 \mathrm{E}+01$ & $1.68 \mathrm{E}+01$ & 97,300 \\
\hline Nickel & $1.70 \mathrm{E}-02$ & 1.61E-02 & $1.45 \mathrm{E}-02$ & $1.18 \mathrm{E}-02$ & 1.41E-02 & $<0.902$ \\
\hline Phosphorus & $3.50 \mathrm{E}-02$ & $<4.22 \mathrm{E}-02$ & $\leq 4.37 \mathrm{E}-02$ & $3.78 \mathrm{E}-02$ & 4.12E-02 & 48.2 \\
\hline Lead & $2.70 \mathrm{E}-01$ & $\leq 5.06 \mathrm{E}-02$ & $\leq 4.78 \mathrm{E}-02$ & $4.68 \mathrm{E}-02$ & 4.84E-02 & $<4.610$ \\
\hline Silicon & $1.23 \mathrm{E}+01$ & $9.91 \mathrm{E}+00$ & $1.00 \mathrm{E}+01$ & $1.04 \mathrm{E}+01$ & $1.01 \mathrm{E}+01$ & 18.9 \\
\hline Tin & $2.70 \mathrm{E}-01$ & $<2.49 \mathrm{E}-02$ & $\leq 2.00 \mathrm{E}-02$ & $\leq 2.43 \mathrm{E}-02$ & 2.31E-02 & 13.4 \\
\hline Strontium & $3.15 \mathrm{E}-02$ & $1.94 \mathrm{E}-02$ & $2.04 \mathrm{E}-02$ & $2.19 \mathrm{E}-02$ & $2.06 \mathrm{E}-02$ & $<0.100$ \\
\hline Titanium & $9.45 \mathrm{E}-02$ & 4.74E-02 & $5.88 \mathrm{E}-02$ & $6.42 \mathrm{E}-02$ & $5.68 \mathrm{E}-02$ & $<0.100$ \\
\hline Vanadium & $6.40 \mathrm{E}-03$ & 6.61E-03 & $6.77 \mathrm{E}-03$ & $1.30 \mathrm{E}-02$ & 8.79E-03 & $\leq 0.368$ \\
\hline Zinc & $6.00 \mathrm{E}-03$ & $\leq 5.74 \mathrm{E}-03$ & $\leq 5.00 \mathrm{E}-03$ & $8.44 \mathrm{E}-03$ & 6.39E-03 & 0.842 \\
\hline Zirconium & & 1.30E-02 & $1.87 \mathrm{E}-02$ & 1.70E-02 & 1.62E-02 & $<0.301$ \\
\hline Uranium & & & & & & \\
\hline Mercury & & 4.84E-03 & $4.46 \mathrm{E}-03$ & $<9.90 \mathrm{E}-03$ & $6.40 \mathrm{E}-03$ & \\
\hline Potassium & & 1.04E-02 & $1.07 \mathrm{E}-02$ & $<1.22 \mathrm{E}-02$ & $1.11 \mathrm{E}-02$ & 159 \\
\hline Arsenic & $2.25 \mathrm{E}-04$ & $<4.96 \mathrm{E}-04$ & $<4.98 \mathrm{E}-04$ & $<2.25 \mathrm{E}-03$ & $1.08 \mathrm{E}-03$ & \\
\hline Selenium & $3.07 \mathrm{E}-04$ & $\leq 5.12 \mathrm{E}-04$ & $<4.98 \mathrm{E}-04$ & $<2.25 \mathrm{E}-03$ & 1.09E-03 & \\
\hline Fluoride & & & & & & 1,653 \\
\hline Chloride & & & & & & 258 \\
\hline Nitrate & & & & & & 50,228 \\
\hline Nitrite & & & & & & 34,784 \\
\hline Sulfate & & & & & & 11,144 \\
\hline Oxalate & & & & & & 1,135 \\
\hline Carbonate & & & & & & 26,404 \\
\hline
\end{tabular}


WSRC-TR-2002-00052

Revision 1

November 22, 2002

Page 18 of 30

Table 5

\section{Tank 19 Chemical Inventories}

\begin{tabular}{|c|c|c|c|}
\hline Species & $\begin{array}{c}\text { Solids Inventory } \\
\text { Based on 120,000 } \\
\text { lb Solids }\end{array}$ & $\begin{array}{c}\text { Supernate Inventory } \\
\text { Based on } 15,000 \\
\text { gallons Supernate }\end{array}$ & $\begin{array}{c}\text { Total Inventory } \\
\text { (Solids + Supernate) }\end{array}$ \\
\hline & $(\mathrm{kg})$ & $(\mathrm{kg})$ & $(\mathrm{kg})$ \\
\hline Silver & 6.0 & & 6.0 \\
\hline Aluminum & $7,415.6$ & 189 & 7,605 \\
\hline Boron & 3.7 & 0.03 & 3.7 \\
\hline Barium & 49.4 & 0.02 & 49.4 \\
\hline Calcium & 496.9 & 0.01 & 497 \\
\hline Cadmium & 5.3 & 0.01 & 5.3 \\
\hline Cerium & 190.9 & - & 190.9 \\
\hline Cobalt & 4.5 & 0.02 & 4.5 \\
\hline Chromium & 19.4 & 1.47 & 20.8 \\
\hline Copper & 2.5 & 0.02 & 2.5 \\
\hline Iron & $1,045.4$ & 0.02 & 1,045 \\
\hline Lanthanum & 8.0 & 0.06 & 8.0 \\
\hline Lithium & 2.0 & 0.02 & 2.0 \\
\hline Magnesium & 137.6 & 0.01 & 137.6 \\
\hline Manganese & 74.6 & 0.01 & 74.6 \\
\hline Molybdenum & 5.0 & 0.15 & 5.2 \\
\hline Sodium & $9,211.1$ & 5,517 & 14,728 \\
\hline Nickel & 7.7 & 0.05 & 7.8 \\
\hline Phosphorus & 22.5 & 2.73 & 25.3 \\
\hline Lead & 26.5 & 0.26 & 26.7 \\
\hline Silicon & $5,529.3$ & 1.07 & 5,530 \\
\hline Tin & 12.6 & 0.76 & 13.4 \\
\hline Strontium & 11.3 & 0.01 & 11.3 \\
\hline Titanium & 31.1 & 0.01 & 31.1 \\
\hline Vanadium & 4.8 & 0.02 & 4.8 \\
\hline Zinc & 3.5 & 0.05 & 3.5 \\
\hline Zirconium & 8.9 & 0.02 & 8.9 \\
\hline Uranium & 93.4 & 0.40 & 93.8 \\
\hline Mercury & 3.5 & & 3.5 \\
\hline Potassium & 6.1 & & 6.1 \\
\hline Arsenic & 0.6 & & 0.6 \\
\hline Selenium & 0.6 & & 0.6 \\
\hline Fluoride & & 93.7 & 93.7 \\
\hline Chloride & & 14.6 & 14.6 \\
\hline Nitrate & & 2,848 & 2,848 \\
\hline Nitrite & & 1,972 & 1,972 \\
\hline Sulfate & & 632 & 632 \\
\hline Oxalate & & 64.4 & 64.4 \\
\hline Carbonate & & 1,497 & 1,497 \\
\hline
\end{tabular}


WSRC-TR-2002-00052

Revision 1

November 22, 2002

Page 19 of 30

\section{Table 6}

\section{Class C Concentration Averaging Calculations}

\begin{tabular}{|c|c|c|c|c|c|c|}
\hline & $\begin{array}{l}\text { Total Inventory } \\
\text { Estimate } \\
\text { (Sludge + } \\
\text { Supernate), Ci }\end{array}$ & $\begin{array}{l}\text { Class C Upper } \\
\text { Limit }\end{array}$ & Class C Units & $\begin{array}{c}\text { Tank } 19 \\
\text { Concentration } \\
\text { in Class C Units }\end{array}$ & $\begin{array}{l}\text { Factor Relative } \\
\text { to Class C Limit }\end{array}$ & $\begin{array}{c}\text { Factor with } 30.6 \\
\text { Inches of Grout } \\
\text { (Sp.G. = 1.94) }\end{array}$ \\
\hline $\mathrm{H}-3$ & $3.88 \mathrm{E}-01$ & None & NA & & & \\
\hline C-14 & $1.04 \mathrm{E}-03$ & $8.00 \mathrm{E}+00$ & $\mathrm{Ci} / \mathrm{m}^{\wedge} 3$ & $1.82 \mathrm{E}-05$ & $2.28 \mathrm{E}-06$ & $0.0000 \%$ \\
\hline Ni-59 & 6.09E-02 & $2.20 \mathrm{E}+02$ & $\mathrm{Ci} / \mathrm{m}^{\wedge} 3$ & $1.07 \mathrm{E}-03$ & $4.88 \mathrm{E}-06$ & $0.0000 \%$ \\
\hline Co-60 & 5.33E-01 & None & NA & & & \\
\hline Se-79 & 5.64E-02 & None & NA & & & \\
\hline Sr-90 & $1.49 \mathrm{E}+03$ & $7.00 \mathrm{E}+03$ & $\mathrm{Ci} / \mathrm{m}^{\wedge} 3$ & $2.62 \mathrm{E}+01$ & $3.75 \mathrm{E}-03$ & $0.0351 \%$ \\
\hline$Y-90$ & $2.65 \mathrm{E}+02$ & None & NA & & & \\
\hline Tc-99 & $6.73 \mathrm{E}+00$ & $3.00 \mathrm{E}+00$ & $\mathrm{Ci} / \mathrm{m}^{\wedge} 3$ & 1.19E-01 & 3.95E-02 & $0.3705 \%$ \\
\hline Ru-106 & $1.99 \mathrm{E}-05$ & None & NA & & & \\
\hline Rh-106 & $1.99 \mathrm{E}-05$ & None & NA & & & \\
\hline Sb-125 & 1.91E-01 & None & $\mathrm{NA}$ & & & \\
\hline Sn-126 & $9.36 \mathrm{E}-03$ & None & NA & & & \\
\hline I-129 & $4.15 \mathrm{E}-07$ & $8.00 \mathrm{E}-02$ & $\mathrm{Ci} / \mathrm{m}^{\wedge} 3$ & 7.31E-09 & $9.13 \mathrm{E}-08$ & $0.0000 \%$ \\
\hline Cs-134 & $5.53 \mathrm{E}-04$ & None & NA & & & \\
\hline Cs-135 & $5.84 \mathrm{E}-05$ & None & NA & & & \\
\hline Cs-137 & $4.87 \mathrm{E}+04$ & $4.60 \mathrm{E}+03$ & $\mathrm{Ci} / \mathrm{m}^{\wedge} 3$ & $8.57 \mathrm{E}+02$ & $1.86 \mathrm{E}-01$ & $1.7476 \%$ \\
\hline Ce-144 & 2.73E-07 & None & NA & & & \\
\hline Pr-144 & 2.73E-07 & None & NA & & & \\
\hline Pm-147 & $3.06 \mathrm{E}+00$ & None & NA & & & \\
\hline Eu-154 & $1.08 \mathrm{E}+00$ & None & $\mathrm{NA}$ & & & \\
\hline Eu-155 & $0.00 \mathrm{E}+00$ & None & NA & & & \\
\hline U-232 & $1.54 \mathrm{E}-05$ & None & NA & & & \\
\hline U-233 & 6.84E-01 & None & NA & & & \\
\hline U-234 & $5.90 \mathrm{E}-01$ & None & NA & & & \\
\hline U-235 & $1.24 \mathrm{E}-03$ & None & $\mathrm{NA}$ & & & \\
\hline U-236 & 5.09E-03 & None & NA & & & \\
\hline U-238 & $4.21 \mathrm{E}-02$ & None & NA & & & \\
\hline Np-237 & $6.42 \mathrm{E}-02$ & 100 & $\mathrm{nCi} / \mathrm{gm}$ & $1.17 \mathrm{E}+00$ & 1.17E-02 & $0.0547 \%$ \\
\hline Pu-238 & $2.27 \mathrm{E}+01$ & 100 & $\mathrm{nCi} / \mathrm{gm}$ & $4.14 \mathrm{E}+02$ & $4.14 \mathrm{E}+00$ & $28.5448 \%$ \\
\hline Pu-239 & $3.00 \mathrm{E}+01$ & 100 & $\mathrm{nCi} / \mathrm{gm}$ & $5.47 \mathrm{E}+02$ & $5.47 \mathrm{E}+00$ & $37.7679 \%$ \\
\hline Pu-240 & $1.06 \mathrm{E}+01$ & 100 & $\mathrm{nCi} / \mathrm{gm}$ & $1.92 \mathrm{E}+02$ & $1.92 \mathrm{E}+00$ & $13.2821 \%$ \\
\hline Pu-241 & $5.40 \mathrm{E}+01$ & 3500 & $\mathrm{nCi} / \mathrm{gm}$ & $9.84 \mathrm{E}+02$ & $2.81 \mathrm{E}-01$ & $1.9393 \%$ \\
\hline Pu-242 & 3.61E-01 & 100 & $\mathrm{nCi} / \mathrm{gm}$ & $6.58 \mathrm{E}+00$ & $6.58 \mathrm{E}-02$ & $0.4544 \%$ \\
\hline Am-241 & $1.15 \mathrm{E}+01$ & 100 & $\mathrm{nCi} / \mathrm{gm}$ & $2.10 \mathrm{E}+02$ & $2.10 \mathrm{E}+00$ & $14.4864 \%$ \\
\hline Am-242m & & 100 & $\mathrm{nCi} / \mathrm{gm}$ & $0.00 \mathrm{E}+00$ & $0.00 \mathrm{E}+00$ & $0.0000 \%$ \\
\hline $\mathrm{Cm}-244$ & 2.24E-04 & 100 & $\mathrm{nCi} / \mathrm{gm}$ & 4.08E-03 & $4.08 \mathrm{E}-05$ & $0.0002 \%$ \\
\hline \multirow[t]{2}{*}{ Cm-245 } & $1.45 \mathrm{E}-10$ & 100 & $\mathrm{nCi} / \mathrm{gm}$ & 2.64E-09 & 2.64E-11 & $0.0000 \%$ \\
\hline & & & & $\begin{array}{c}\text { Sum of Class C } \\
\text { Factors }\end{array}$ & 14.2 & 0.997 \\
\hline
\end{tabular}




\subsection{Estimated Inventories}

\subsubsection{Radionuclide Inventories}

The estimated inventories of contaminants in Tank 19 are reported in Table 3. For each nuclide that is significant to tank closure, the inventory of that nuclide in the tank was estimated both by samples and process knowledge. The inventories reported for these key constituents are based on sample data. For all other radionuclides, the inventories are based on process knowledge estimates. For nuclides for which sample data is available, an upper $95 \%$ confidence limit on the average concentration is reported. As mentioned previously, in computing the sample average and upper $95 \%$ confidence limit, the sample of crusty material (Sample No. 1) was ignored, although the composition of this material is reported in Table 2 for comparison.

The formula used for computing the upper $95 \%$ confidence limit for each nuclide was

UpperBound $=$ Mean $+s \frac{(\text { Upper Cutoff }, 95 \%)}{\sqrt{\text { Number of samples }}}$

Where:

UpperBound = upper $95 \%$ confidence limit on the average concentration Mean $=$ mean of the available samples

$\mathrm{s}=$ sample standard deviation

Upper Cutoff, 95\% = Upper Cutoff from the standard one-tailed Students t-table at 95\% confidence, as follows:

\begin{tabular}{|l|l|l|}
\hline $\begin{array}{l}\text { Number of } \\
\text { Samples }\end{array}$ & $\begin{array}{l}\text { Degrees of } \\
\text { Freedom }\end{array}$ & $\begin{array}{l}\text { One-tailed Cutoff, } \\
95 \% \text { confidence }\end{array}$ \\
\hline & & \\
\hline 2 & 1 & 6.31375 \\
\hline 3 & 2 & 2.91999 \\
\hline 4 & 3 & 2.35336 \\
\hline
\end{tabular}

For most nuclides, the value estimated from samples was higher than process knowledge, indicating perhaps that absorption on the zeolite (or some other mechanism) has enriched the concentration of these nuclides. Chemical analysis of the crusty material showed that the original zeolite in the tank is significantly degraded to other mineral compounds. In fact, none of the original zeolite added to the tank was detected in this sample. Instead, degraded forms of mineral compounds were found that evidently formed from reactions between the original zeolite and the waste that was added to the tank. ${ }^{6}$

Like the original zeolite, these new compounds still have the ability to absorb certain cations, as evidenced by the higher-than-expected concentration for Cs-137. The Cs-137 
concentration is more than three orders of magnitude higher than its process knowledge estimate. However, Cs-137 has a relatively short half-life (30 years) compared to the times for contaminants to move significantly from a closed waste tank (hundreds of years). Thus, the elevated level of Cs-137 is not a performance assessment concern. Tc99, the major contributor to the tank seepline dose performance, is about 4 times its expected concentration.

To calculate the Tank 19 radionuclide inventory in the solids heel, the estimated radionuclide concentrations (on a curie per unit weight basis) were multiplied by the $120,000-1 b$ of dry sludge calculated (in Section 5.1) to remain in the tank. To calculate the radionuclide inventory in the supernate, the measured radionuclide concentrations from the supernate sample (on a curie per unit volume basis) were multiplied by the 15,000 gallons of supernate estimated (in Section 5.2) to remain in the tank.

In the total tank radionuclide inventory, however, some of the radionuclide inventory of the interstitial supernate in the solids were doubly accounted for. When the solids samples were analyzed in the lab, they were weighed, dried to a constant temperature, and then weighed again. From the difference in weights, the interstitial liquid (supernate) in the solids samples was estimated to be around $25-35 \mathrm{wt} \%$. This is less than the 85 vol\% interstitial supernate assumed to exist in the tank solids heel due to leakage of supernate from the sampler-it was not designed to be water-tight — and also to evaporation. Due to the radioactivity contribution of the 25-35 wt\% supernate in the solids samples, it is estimated that the radioactivity of around 1,200 gallons of supernate were double counted in the solids radionuclide inventory. Reducing the volume of supernate used to calculate the supernate radionuclide inventory by 1,200 gallons would only decrease the Tc-99 inventory in the tank by less than $0.5 \%$. For conservatism, this was not taken into account in calculating the supernate radionuclide inventory; the supernate volume used to calculate the supernate radionuclide inventory was equal to the 15,000 gallons of supernate estimated to remain in the tank.

\subsubsection{NRC Class C Calculation}

Table 6 is a Class $\mathrm{C}$ calculation for the waste in Tank 19. The column entitled "Class C Upper Limit" shows the Class $\mathrm{C}$ limit for each radionuclide, from Nuclear Regulatory Commission regulation 10 CFR 61.55, effective 1991. The units for the value in the column are shown in the next column, entitled "Class C Units." The next column, "Tank 19 Concentration in Class Units," shows the computed concentration of the Tank 19 sludge converted to the appropriate units.

In the column "Factor relative to Class $\mathrm{C}$ Limit," the computed concentration in Tank 19 is divided by the limit to obtain a Class $\mathrm{C}$ factor for each radionuclide. To be within the Class $\mathrm{C}$ designation the sum of all of these factors must be less than or equal to 1 . As can be seen from the sum at the bottom of the column, the solids in Tank 19 are currently 14 times the upper concentration limit for Class $\mathrm{C}$ waste. These concentrations are calculated from the total curies in the tank (from both the solids heel and the free 
supernate) and the volume of the solids heel $(15,000 \mathrm{gal})$. This is conservative because it does not credit the volume of the free supernate $(1,800 \mathrm{gal})$.

The last column, "Factor with 30.6 Inches Grout," shows the factors if one takes credit for the mass of 30.6 inches of grout covering the entire tank floor in computing the radionuclide concentration. The reducing grout planned for use in the first layer has a specific gravity of 1.94. As can be seen from the summation at the bottom of the column, 30.6 inches of grout is sufficient to bring the sum of the Class $\mathrm{C}$ factors to less than 1.000. A number below 1.000 means that the average concentration of the waste plus grout in Tank 19 will be less than the upper limit for Class $C$ waste. The contribution of each nuclide to the sum of the Class $\mathrm{C}$ factors is calculated with the following formula:

$$
\text { Factor }=\frac{I}{C \times h_{\text {grout }} \times A_{\tan k} \times \rho_{\text {grout }}}
$$

where:

Factor $=$ individual radionuclide contribution to the sum of the Class $\mathrm{C}$ factors

$I=$ inventory of radionuclide in tank $(\mathrm{Ci})$

$C=$ Class $\mathrm{C}$ concentration limit (nCi/g)

$h_{\text {grout }}=$ height of encapsulating grout used for concentration averaging (in.)

$A_{\text {tank }}=$ cross-sectional area of the tank $\left(\mathrm{ft}^{2}\right)$

$\rho_{\text {grout }}=$ grout density $(\mathrm{g} / \mathrm{mL})$

For example, the following calculates the contribution of $\mathrm{Pu}-238$ to the sum of the Class $\mathrm{C}$ factors when crediting 30.6 inches of grout for concentration averaging:

$$
\text { Factor }=\frac{22.7 C i \times 1,000,000,000 \frac{n C i}{C i}}{\frac{100 n C i}{g} \times 30.6 i n \times 5674.5 f t^{2} \times \frac{144 i n^{2}}{1 f t^{2}} \times \frac{1.94 g}{m L} \times \frac{1,000 m L}{L} \times \frac{1 L}{61.025 \mathrm{in}^{3}}}=0.29
$$

In the two previous closures at SRS (Tanks 17 and 20) a safety factor of 50\% was applied to the volume of grout used to compute the Class $\mathrm{C}$ factors. These closures were approved by the South Carolina Department of Health and Environmental Control (SCDHEC) and reviewed extensively by the NRC. Thus, the $50 \%$ safety factor represents a level of conservatism agreed to by the regulators. Including this safety factor, it is recommended that at least 46 inches of grout (at a specific gravity of 1.94) be poured in the first layer to ensure that the average concentrations are below Class $\mathrm{C}$ limits.

The grout designed for use in Tank 19 has not yet been approved for closure, and there is a possibility that the grout used for Tanks 17 and 20, which had a specific gravity of 2.4, will be used instead. In this case, 24.9 inches of grout will be needed to bring the sum of the Class $\mathrm{C}$ factors to less than 1.000. Applying a safety factor of $50 \%$ increases the amount of grout required for this option to 37 inches. 


\subsubsection{Chemical Inventories}

Table 4 shows the concentrations of chemical constituents in the solids and supernate samples taken from Tank 19. As mentioned previously, the sample of crusty material (Sample No. 1) was ignored in calculating the average concentration of each constituent in the tank, although the composition of this sample is reported in Table 4 for comparison. Table 5 shows the chemical inventories of the residual tank heel based on the sample concentration data in Table 4 . The chemical inventory of the tank solids was calculated by multiplying the reported average of the chemical concentrations in the solids samples by the $120,000 \mathrm{lb}$ of solids estimated to remain in the tank. The chemical inventory of the supernate was calculated by multiplying the chemical concentrations in the supernate sample by the 15,000 gallons of supernate estimated to remain in the tank. The total tank inventory was calculated by adding the solids and supernate inventories.

\subsubsection{Inventory of Purex Low Heat Waste}

Tank 19 has a much larger quantity of solids than the other two tanks that have been closed, Tanks 17 and 20. However, the amount of Purex waste that contributed to the solids in Tank 19 is approximately double the amount that remained in Tank 17.

The Tank 19 solids came from three different sources:

- Zeolite-This was used in a cesium removal column that was used to decontaminate evaporator overheads. The spent zeolite resin from the column was dumped into the tank. The zeolite was in the form of relatively large, fast settling solids. The presence of zeolite and compounds derived from it is thought to be the reason that waste removal from the tank was so difficult, since these solids were difficult to suspend and transfer.

- Coating waste-Coating waste was the waste produced when the cladding (the coating) was stripped off SRS target tubes containing depleted uranium and plutonium. The tubes were clad with aluminum, which has a low neutron cross section and thus would not accumulate much radioactive materials. The cladding was stripped off using sodium hydroxide. The resulting waste was very low in radioactivity and was sent primarily to Type IV tanks (the single-walled tanks).

- Purex Low Heat Waste-This is the High Level Waste that is responsible for most of the radionuclides in Tank 19. Wastes from the first cycle of solvent extraction in the F-Area Canyon are called Purex High Heat Waste. Purex Low Heat Waste includes all other wastes, from second cycle, any subsequent cycles, and other sources.

The amount that each source contributed to the solids in Tank 19 can be estimated from the Tank 19 chemical compositions. Purex Low Heat Waste contains about 24 wt\% iron ${ }^{11}$ and is assumed to be the only source that contained a significant amount of iron. Thus, it can be assumed that most of the iron in the tank came from Purex Low Heat Waste. This is conservative because it does not take into account iron from airborne dust/dirt from continuous ventilation for 40 years, tank corrosion, and impurity iron in the zeolite (chabazite mined from natural deposits). Zeolite is primarily sodium 
WSRC-TR-2002-00052

Revision 1

November 22, 2002

Page 24 of 30

aluminosilicates and is the only source that contained a significant amount of silicon.

Thus, it can be assumed that most of the silicon in Tank 19 came from zeolite.

Unfortunately, coating waste contains no signature element. It is largely aluminum hydroxide. Aluminum is also in Purex Low Heat Waste and zeolite.

Assuming the zeolite can be represented by hydrated sodalite with a chemical formula of $\mathrm{Na}_{8}\left(\mathrm{Al}_{6} \mathrm{Si}_{6} \mathrm{O}_{24}\right)\left(\mathrm{NO}_{3}\right)_{2} * 4 \mathrm{H}_{2} 0$, the compositions of the major chemical constituents in Tank 19, Purex Low Heat Waste, and hydrated sodalite are as follows:

\begin{tabular}{ccc}
$\begin{array}{c}\text { Tank 19 } \\
\text { Samples } \\
(\mathrm{wt} \%)\end{array}$ & $\begin{array}{c}\text { Purex } \\
\text { LHW } \\
(\mathrm{wt} \%)\end{array}$ & $\begin{array}{c}\text { Hydrated } \\
\text { sodalite } \\
(\mathrm{wt} \%)\end{array}$ \\
\hline
\end{tabular}

$\begin{array}{lccc}\mathrm{Al} & 13.5 & 4.7 & 14.8 \\ \mathrm{Fe} & 1.9 & 24.3 & 0.0 \\ \mathrm{Na} & 16.8 & 3.8 & 16.8 \\ \mathrm{Si} & 10.1 & 0.9 & 15.4 \\ & & & \\ & 42.4 & 33.6 & 47.0\end{array}$

Based on this information, the amounts that each source contributed to the solids in Tank 19 can be calculated as follows:

\begin{tabular}{lccc} 
Constituent & $\begin{array}{c}\text { Estimated } \\
\text { wt\% }\end{array}$ & $\begin{array}{c}\text { Mass in Tank } \\
(\mathrm{lb})\end{array}$ & Based on: \\
\hline Zeolite (hydrated sodalite) & 65.6 & 78,737 & $\mathrm{Si}$ \\
Purex Low Heat Waste & 7.9 & 9,429 & $\mathrm{Fe}$ \\
Other (primarily coating waste) & 26.5 & 31,834 & Balance \\
& & & \\
Totals & 100.0 & 120,000 &
\end{tabular}

The estimated quantity of Purex Low Heat Waste that contributed to the samples, 9,429 $\mathrm{lb}$, is about twice the quantity left in Tank 17 when it was closed, about 4,700 lb. The Tank 17 solids contained about 24\% iron, exactly the concentration of iron in Purex Low Heat Waste. Thus, all the insoluble solids in the tank at closure ${ }^{1}$ appeared to be derived almost exclusively from Purex Low Heat Waste. Even though Tank 19 has about 7 times the volume of solids in Tank 17 (15,000 gallons vs 2,200 gallons), the mass due to Purex Low Heat Waste is only about twice that of Tank 17.

Tank 20 had about 1,950 lbs of solids at the time of closure. The sample of the bulk of the heel material taken in preparation for closure in which the iron concentration was directly measured had an iron concentration of $7.9 \mathrm{wt} \% .^{2}$ Thus, a best guess estimate of 
the percentage of Purex Low Heat Waste that contributed to the solids is $7.9 / 24.3=33 \mathrm{wt}$ $\%$. Thus, a reasonable estimate is that $630 \mathrm{lbs}$ of Purex Low Heat Waste contributed to the solids in Tank 20 .

\subsubsection{Other Contaminants}

Six risers in Tank 19 contain lead, which acted as radiation shielding when the tank stored HLW. Plans are to leave these risers in place when the tank is closed. These six risers contain an estimated total of 7750 pounds of lead.

In addition to the contaminants in Tanks 17-20, there will be contamination in other equipment in the area, such as the 1F Evaporator, the 1F Concentration Transfer System, ventilation systems, and transfer piping. The inventory of contaminants in these locations is expected to be small relative to the amount of contamination in the tanks.

To account for contamination above the level of reducing grout, outside of the tank, and in ancillary equipment and piping, an inventory of contaminants equal to $20 \%$ of the waste inside the tank should be added to the performance modeling for each waste tank in the Tank 17-20 area. Based on engineering judgment, this $20 \%$ should bound the contamination in these locations. As closure modules are prepared for these locations, the modules will show that the contamination left behind is smaller than this estimate, or the estimate will be revised and the performance evaluation repeated.

\section{Analysis of Possible Fixed Contamination on the Tank 19 Interior Surfaces}

See Appendix.

\section{Revision to F Tank Farm Inventory Estimates}

Np-237 is the nuclide that dominates the alpha concentration estimated for the seepline, so a correct estimate of this radionuclide is desirable. The estimated inventory of Np-237 in Tank 19 is $0.064 \mathrm{Ci}$, as compared to the Tank 17 estimate of $0.015 \mathrm{Ci}^{1}{ }^{1}$ The estimated inventory used in the General Closure plan for all of F Tank Farm is $0.060 \mathrm{Ci}$. Thus, the total of Tank 17 and $19(0.079 \mathrm{Ci})$ is more than the estimated inventory for all the tanks to be closed in F Tank Farm. The estimated inventory for F area is low.

A review of the source of this information, the Waste Characterization System, ${ }^{8}$ indicates that there is no basis for changing the inventory estimates for Tanks 1-8. For the period that the tanks were being filled, the Waste Characterization System assumes that all of the Np-237 introduced into F Tank Farm went into these tanks and none of the Np-237 went to Tanks 17-20. Thus, the estimate for Tanks 1-8 is probably conservatively high, and the estimate for Tank 17-20 is low.

Another factor contributing to the apparent discrepancy is different assumptions of the amount of residual solids that will be left in Tanks 1-8 versus Tanks 17-20. According to the closure plan, plans are to reduce the residual inventory in Tanks 1-8 to 100 gallons of 
waste per tank, about 200 lbs (assuming a bulk density of $1.95 \mathrm{lb} / \mathrm{gal}$ ) so the total inventory of these tanks after closure is estimated as equivalent to 1,600 lbs of Purex waste. Tanks 1-8 contain Purex High Heat Waste, which has much higher levels of some radionuclides, especially Tc-99 and Plutonium isotopes, which are significant to tank closure as discussed in previous sections.

The total inventory of equivalent Purex waste in Tanks 17, 19, and 20 is 4,700 +9,400+ $630 \mathrm{lbs}=14,700 \mathrm{lbs}$ of waste. Thus, the equivalent Purex waste in these three tanks alone is almost ten times the estimated equivalent waste in Tanks 1-8.

For the purposes of estimating future doses from $\mathrm{F}$ Tank Farm, it is recommended that the following guidelines be used:

- For Tanks 17, 19, and 20, use the actual inventories estimated in this report and in references 1 and 2.

- For Tank 18, assume that the waste has the same composition as Tank 17 waste (much of the waste in Tank 18 actually came from Tank 17) and use the residual volume goal for Tank 18. Tank 17 contained $0.015 \mathrm{Ci}$ of Np-237 in 2,200 gallons of Purex waste.

- For Tanks 1-8, continue to use the estimate of $0.06 \mathrm{Ci}$ of $\mathrm{Np}-237$ unless the volume goal of 100 gallons per tank is changed. If the goal is changed, adjust this value accordingly.

\section{References}

${ }^{1}$ P. D. d'Entremont, J. R. Hester, and T. B. Caldwell, "Characterization of Tank 17 Residual Waste," WSRC-TR-97-0066, Rev. 1, September 22, 1997

2 P. D. d'Entremont and J. R. Hester, "Characterization of Tank 20 Residual Waste," WSRC-TR-96-0267, March 17, 1997

${ }^{3}$ Jonathan Thomas, "Tank 19 Heel, Supernate, and Possible Unmoved Heel Mounds Volume Calculation,” Calculation Note G-CLC-F-00180, Rev. 1, February 25, 2002

${ }^{4}$ L. F. Landon and T. T. Thompson, "Technical Data Summary for the Defense Waste Processing Facility, Stage 2," DPSTD-80-39-2, December 1980

${ }^{5}$ R. F. Swingle, "Densities of the Tank 19F Closure Grab and Core Samples," WSRCTR-2002-00453, September 30, 2002

${ }^{6}$ R. F. Swingle, N. E. Bibler, and A. A. Ekechukwu, "Data Report: Tank 19F NE Riser Zeolite Mound Sample Analysis,” WSRC-RP-2001-00410, April 17, 2001

${ }^{7}$ R. F. Swingle, "Characterization of the Tank 19F Closure Grab and Core Samples and the Tank 18F Dip Sample," WSRC-TR-2002-00107, March 6, 2002 
WSRC-TR-2002-00052

Revision 1

November 22, 2002

Page 27 of 30

${ }^{8}$ J. R. Hester, "High Level Waste Characterization System," WSRC-TR-96-0264, December 1996

${ }^{9}$ P. D. d'Entremont and D. T. Bignell, "Options for Meeting Class C Criteria During HLW Tank Closure," WSRC-TR-96-0327, 16 October 1996

${ }^{10}$ J. R. Fowler, "Waste Composition at the Savannah River Plant—Update," DPST-83313, February 28, 1983.

${ }^{11}$ R. F. Swingle, "Reanalysis of Plutonium and Americium-241 in the Tank 19F Closure Grab and Core Samples," WSRC-TR-2002-00540, November 21, 2002 


\section{APPENDIX}

ESTIMATION OF THE POTENTIAL CONTAMINATION ON THE INTERIOR SURFACE CORROSION PRODUCTS IN TANK 19 


\section{Introduction and Summary}

In support of Tank 19 closure, DOE requested that High Level Waste perform a quantitative analysis and evaluation to address any fixed contamination that may be present on the internal tank surfaces. A visual examination of video footage of the Tank 19 interior concluded that corrosion of the carbon steel walls had been light and general. Using general corrosion rates from laboratory and field test data and historical ultrasonic tank thickness measurements, the Savannah River Technology Center (SRTC) estimated that there were 497 pounds of corrosion product (rust) that had been exposed to radioactive waste on the tank interior surfaces ${ }^{1}$. High Level Waste provided SRTC data concerning the concentration of radionuclides present in the supernate historically in contact with the tank interior surfaces. SRTC then used measured $\mathrm{K}_{\mathrm{d}}$ values, which quantify how key constituents partition between a solid and a liquid phase in contact with each other, to calculate the potential amount of radioactive contamination absorbed onto the 497 pounds of corrosion products ${ }^{2}$. Table 1 summarizes the calculated radioactive contamination on the tank interior corrosion products and compares it to the amount of radioactive inventory in the bottom residual heel of Tank 19:

Table 1. Comparison of Calculated Rust Residual Contamination and Bottom Residual in Tank 19

\begin{tabular}{|c|c|c|c|}
\hline Radionuclide & $\begin{array}{c}\text { Wall Residual } \\
\text { Contamination, } \mathrm{Ci}\end{array}$ & $\begin{array}{l}\text { Residual Sludge and } \\
\text { Supernate in Heel, Ci }\end{array}$ & $\begin{array}{l}\text { Wall Residual as } \\
\text { Percentage of Heel }\end{array}$ \\
\hline${ }^{3} \mathrm{H}$ & 0 & 0.39 & $0 \%$ \\
\hline${ }^{79} \mathrm{Se}$ & 0.19 & 0.056 & $337 \%$ \\
\hline${ }^{90} \mathrm{Sr}^{\mathrm{a}}$ & $4.6 \mathrm{E}-04^{\mathrm{b}}$ & 1,490 & $0 \%$ \\
\hline${ }^{99} \mathrm{Tc}$ & 0 & 6.7 & $0 \%$ \\
\hline${ }^{134} \mathrm{Cs}^{\mathrm{a}}$ & $2.9 \mathrm{E}-04^{\mathrm{b}}$ & $5.5 \mathrm{E}-04$ & $52 \%$ \\
\hline${ }^{137} \mathrm{Cs}^{\mathrm{a}}$ & $200^{\mathrm{a}}$ & 48,677 & $0 \%$ \\
\hline${ }^{137} \mathrm{Cs}$ & 4.9 & 48,677 & $0 \%$ \\
\hline${ }^{233} \mathrm{U}$ & $6.3 \mathrm{E}-02$ & 0.68 & $9 \%$ \\
\hline${ }^{234} \mathrm{U}$ & 4.1E-02 & 0.59 & $7 \%$ \\
\hline${ }^{235} \mathrm{U}$ & $1.1 \mathrm{E}-04$ & $1.2 \mathrm{E}-03$ & $9 \%$ \\
\hline${ }^{236} \mathrm{U}$ & $4.2 \mathrm{E}-04$ & $5.1 \mathrm{E}-03$ & $8 \%$ \\
\hline${ }^{238} \mathrm{U}$ & $3.0 \mathrm{E}-03$ & 0.042 & $7 \%$ \\
\hline${ }^{237} \mathrm{~Np}$ & 5.7E-04 & 0.064 & $1 \%$ \\
\hline \multicolumn{4}{|l|}{$\mathrm{Pu}^{\mathrm{a}}$} \\
\hline${ }^{238} \mathrm{Pu}$ & $2.2^{\mathrm{b}}$ & 22.7 & $10 \%$ \\
\hline${ }^{239} \mathrm{Pu}$ & $0.33^{b}$ & 30.0 & $1 \%$ \\
\hline${ }^{238} \mathrm{Pu}$ & 0.44 & 22.7 & $2 \%$ \\
\hline${ }^{239} \mathrm{Pu}$ & 0.19 & 30.0 & $1 \%$ \\
\hline${ }^{240} \mathrm{Pu}$ & 0.50 & 10.6 & $5 \%$ \\
\hline${ }^{241} \mathrm{Pu}$ & 0.60 & 54 & $1 \%$ \\
\hline${ }^{242} \mathrm{Pu}$ & $8.3 \mathrm{E}-03$ & 0.36 & $2 \%$ \\
\hline${ }^{241} \mathrm{Am}$ & 0.13 & 11.5 & $1 \%$ \\
\hline
\end{tabular}

${ }^{a}$ from 1975 analysis of Tank 19 contents

${ }^{\mathrm{b}}$ decay corrected from 1975 
WSRC-TR-2002-00052

APPENDIX

November 22, 2002

Page 30 of 30

\section{Conclusions}

The calculated amount of radioactive contamination on the interior rust in Tank 19 is compared to the amount of radioactive inventory in the bottom residual heel in Table 1. Fate and transport groundwater modeling assesses the environmental impact of closing HLW tanks with the residual radioactive heel remaining at closure. This model currently factors in an additional $20 \%$ of the bottom residual inventory to account for any radioactivity distributed above the level of reducing grout and in the ancillary equipment and piping associated with the tank system. Table 1 shows that, for most of the radionuclides, the wall residual contains less than $20 \%$ of the activity that is present in the bottom heel. There are a couple radionuclides that exceed this percentage, but they are ones with very low inventories - cesium-134 (2.9E-4 Ci) and selenium-79 $(0.19 \mathrm{Ci})$.

Thus, the residual contamination on the walls of Tank 19 is safely accounted for with the $20 \%$ additional activity factored into the tank inventory in the fate and transport groundwater model.

\section{References}

${ }^{1}$ Bruce Wiersma, "Calculation of the Amount of Corrosion Product in HLW Tank 19," SRT-MTS-2002-20004, Rev. 1, February 8, 2002

${ }^{2}$ Jim Cook, "Estimation of the Potential Contamination on Corrosion Products in Tank 19,” SRT-WED-2002-00016, Rev. 2, October 17, 2002 